\title{
Comparative efficacy and safety of first-line treatments in patients with metastatic renal cell cancer: a network meta- analysis based on phase 3 RCTs
}

\author{
Xiaofeng Chang ${ }^{1,2,4}$, Fan Zhang ${ }^{1}$, Tieshi Liu ${ }^{1}$, Rong Yang ${ }^{1}$, Changwei $\mathrm{Ji}^{1}$, Xiaozhi \\ Zhao $^{1}$, Linfeng $X \mathbf{u}^{1}$, Guangxiang Liu' ${ }^{1}$ and Hongqian Guo ${ }^{1,3}$ \\ ${ }^{1}$ Department of Urology, The Affiliated Nanjing Drum Tower Hospital, Medical School of Nanjing University, Nanjing, China \\ 2 Jiangsu Key Laboratory of Molecular and Functional Imaging, Department of Radiology, Zhongda Hospital, Medical School, \\ Southeast University, Nanjing, China \\ ${ }^{3}$ Medical School, Southeast University, Nanjing, China \\ ${ }^{4}$ Collaborative Innovation Center of Suzhou Nano-Science and Technology, Suzhou Key Laboratory of Biomaterials and \\ Technologies, Suzhou, China
}

Correspondence to: Hongqian Guo, email: dr.guohq@gmail.com

Keywords: metastatic renal cell carcinoma, efficacy, safety, therapy, meta-analysis

Received: October 22, $2015 \quad$ Accepted: February 11, 2016 Published: February 19, 2016

\section{ABSTRACT}

It is impossible to conduct head-to-head trials of all the therapies to determine optimal treatment in the rapidly advancing era of therapies for metastatic renal cell carcinoma ( $\mathrm{mRCC})$. In this network meta-analysis, we aimed to compare efficacy and safety of first-line treatments for mRCC. We searched PubMed, Embase, the Cochrane Central Register of Controlled Trials, and unpublished studies were also sought through "clinicaltrials.gov" from their inception through January 31, 2016. A database search identified 1253 articles, with 11 studies meeting the eligibility criteria. A total of 7597 patients in twelve different treatment arms were assessed. Network meta-analysis showed sunitinib had a significantly longer PFS than IFN-a (SMD=5.68; 95\%CI: $-10.76,-0.86 ; P<0.001)$ and placebo (SMD =-6.71; 95\%CI: $-12.65,-$ 0.79; $P<0.001)$, meanwhile, pazopanib had a significantly longer PFS compared with placebo $(S M D=5.13 ; 95 \% C I: 0.43,10.09 ; P<0.001)$. The cumulative ranking probability curve indicated that sunitinib had the highest probability of being the best treatment modality in terms of PFS and it also had the highest probability of being the safest drugs as the first-line treatment when it came to SAE. Thus, sunitinib might be the best choice of first-line treatment for patients with $\mathrm{mRCC}$ because it has the most favorable balance between efficacy and safety.

\section{INTRODUCTION}

Renal cell carcinoma (RCC) accounts for $85 \% 90 \%$ of primary renal malignant tumors, which results in more than 120000 new cases in Europe and the USA every year, and causes about 60000 deaths[1]. Most of these cases are clear-cell renal cell carcinomas [2]. Up to $30 \%$ of patients have metastases at the time of the initial diagnosis, resulting in poor prognosis and subsequent 5 -year survival rate of only $12 \%$ [3] Until 2005, only interleukin-2 (IL-2) was approved by FDA to be used in the systemic therapy of mRCC, and occasional and continuous complete response could be achieved when high-dose IL-2 was administrated. Interferon-alfa (IFN- $\alpha$ ) is another cytokine therapy which is also widely used in the systemic therapy of mRCC. A meta-analysis based on randomized controlled trials (RCTs) has shown that patients with $\mathrm{mRCC}$ could benefit modest response rate from IFN- $\alpha$ [4].

The greater and deeper understanding of the mechanisms involved in the pathogenesis of $\mathrm{mRCC}$ led to development of more promising target treatment options $[5,6]$. Previous RCTs of targeted therapies versus cytokine therapies or placebos manifested that targeted therapies showed superiority in PFS, response, and tolerability [7, 8]. Since 2005 , several targeted drugs in treating mRCC have been approved by FDA. Even though most of patients with mRCC could benefit a lot from these targeted 
Table1: Summary of trial characteristics.

\begin{tabular}{|c|c|c|c|c|c|}
\hline Author/Trial, Year(reference) & $\begin{array}{l}\text { Total } \\
\text { sample } \\
\text { size(n) }\end{array}$ & Agent(s) & Comparator & \begin{tabular}{|l|} 
Pri- \\
mary \\
out- \\
come \\
\end{tabular} & Other outcomes \\
\hline $\begin{array}{l}\text { Motzer RJ et al./ } \\
\text { NCT00083889,2009 [09] }\end{array}$ & 750 & Sunitinib & IFN- $\alpha$ & PFS & ORR,OS,SAE,death \\
\hline $\begin{array}{l}\text { Sternberg CN et al./ } \\
\text { NCT00334282,2010 [10] }\end{array}$ & 435 & Pazopanib & Placebo & PFS & ORR,OS,SAE,death \\
\hline Gore ME et al.,2010 [11] & 1006 & IFN- $\alpha$ & IFN- $\alpha+$ IL-2+fluorouracil & OS & ORR,PFS,SAE,death \\
\hline Escudier B et al.,2010 [12] & 649 & Bevacizumab+IFN- $\alpha$ & IFN- $\alpha+$ placebo & OS & ORR,PFS,SAE,death \\
\hline Rini BI et al.,2010 [13] & 732 & Bevacizumab+IFN- $\alpha$ & IFN- $\alpha$ & OS & ORR,PFS,SAE,death \\
\hline Rini BI et al.,2014 [14] & 791 & Temsirolimus+bevacizumab & IFN- $\alpha+$ bevacizumab & PFS & ORR,OS,SAE,death \\
\hline $\begin{array}{l}\text { Escudier B et al./ } \\
\text { NCT00073307,2009 [15] }\end{array}$ & 903 & Sorafinib & Placebo & OS & ORR,PFS,SAE,death \\
\hline $\begin{array}{l}\text { Motzer RJ et al./ } \\
\text { NCT00720941,2013 [16] }\end{array}$ & 1110 & Pazopanib & Sunitinib & PFS & ORR,OS,SAE,death \\
\hline Motzer RJ et al.,2013 [17] & 517 & Tivozanib & Sorafinib & PFS & ORR,OS,SAE,death \\
\hline $\begin{array}{l}\text { Hutson TE et al./ } \\
\text { NCT00920816,2013 [18] }\end{array}$ & 288 & Axitinib & Sorafinib & PFS & ORR, SAE,death \\
\hline $\begin{array}{l}\text { Hudes } \mathrm{G} \text { et al./ NCT00065468,2007 } \\
\text { [19] }\end{array}$ & 416 & IFN- $\alpha$ & Temsirolimus & OS & PFS,SAE, death \\
\hline
\end{tabular}

Abbreviations: $\mathrm{ORR}=$ Objective response rate, $\mathrm{PFS}=$ Progression free survival, $\mathrm{OS}=$ Over-all survival, $\mathrm{SAE}=$ serious adverse events, IL-2=Interleukin-2, IFN=Interferon

therapies, little continuous response has been reported. Numerous RCTs are ongoing to evaluate new drugs or therapeutic schedules for mRCC; however, it is impossible to conduct head-to-head evaluations of all the therapies to determine optimal treatment in the rapidly advancing era of targeted therapies. Given this, we reviewed all the RCTs and conducted a network meta-analysis to provide a clinically useful summary of the results that can be used to guide treatment decisions.

\section{RESULTS}

\section{Study characteristics}

Our search strategy yielded 1253 potential relevant studies, of which 169 potential eligible articles were analyzed and 158 reports that did not meet eligibility criteria were excluded from our analysis (Figure 1). Thus, there were altogether 11 studies up to January 2016 found to be eligible for the final network meta-analysis [9-19]. Table 1 summarizes the characteristics of the included trials. A total of 7597 patients in twelve different treatment arms were assessed: IFN- $\alpha$ alone, temsirolimus alone, sorafinib alone, sunitinib alone, pazopanib alone, axitinib alone, tivozanib alone, IFN- $\alpha+$ IL-2 + fluorouracil, bevacizumab + IFN- $\alpha$, IFN- $\alpha+$ placebo, temsirolimus+bevacizumab and placebo. Figure 2 shows the network of eligible comparisons for the network metaanalysis.

\section{Results from direct comparisons}

We did direct comparisons with regard to the efficacy and safety of the therapies for mRCC (Table 2). Among the 11 studies, no repeated comparisons appeared in different studies. Data of progression free survival (PFS) and serious adverse events (SAEs) were reported in every study. Data from 11 selected RCTs showed that efficacy favored tivozanib over sorafinib (SMD = $-0.16 ; 95 \%$ CI:-0.34,0; $P<0.05)$, bevacizumab + IFN- $\alpha$ over IFN- $\alpha+$ placebo $(\mathrm{SMD}=-6.85 ; 95 \% \mathrm{CI}:-7.25,-6.45 ; P<$ $0.001)$, bevacizumab+IFN- $\alpha$ over IFN- $\alpha$ (SMD = -0.29; 95\%CI: $-0.43,-0.14 ; P<0.05$ ), sunitinib over IFN- $\alpha$ (SMD $=-0.61 ; 95 \% \mathrm{CI}:-0.75,-0.46 ; P<0.05)$, temsirolimus over IFN- $\alpha$ (SMD $=-0.26 ; 95 \% \mathrm{CI}:-0.46,-0.07 ; P<$ $0.05)$, pazopanib over placebo $(\mathrm{SMD}=-7.13 ; 95 \% \mathrm{CI}$ : $-7.64,-6.62 ; P<0.001)$, and sorafinib over placebo $(\mathrm{SMD}=-3.37 ; 95 \% \mathrm{CI}:-3.58,-3.17 ; P<0.001)$. With regard to safety, the results showed that safety favored tivozanib over sorafinib $(\mathrm{RR}=0.88 ; 95 \% \mathrm{CI}$ : 0.78,1.00; $P$ $<0.05)$, IFN $-\alpha+$ placebo over bevacizumab + IFN $-\alpha$ $(\mathrm{RR}=1.82 ; 95 \% \mathrm{CI}: 1.35,2.44 ; P<0.05)$, IFN- $\alpha$ over bevacizumab+IFN- $\alpha \quad(\mathrm{RR}=1.27 ; 95 \% \mathrm{CI}: 1.15,1.39 ; P$ $<0.05)$, sunitinib over IFN- $\alpha(\mathrm{RR}=0.57 ; 95 \% \mathrm{CI}$ : $0.46,0.70 ; P<0.05)$, temsirolimus + bevacizumab over IFN$\alpha+$ bevacizumab $(\mathrm{RR}=1.19 ; 95 \% \mathrm{CI}: 1.01,1.41 ; P<0.05)$, temsirolimus over IFN- $\alpha(\mathrm{RR}=0.42 ; 95 \% \mathrm{CI}: 0.27,0.67 ; P$ $<0.05$ ), and placebo over sorafinib $(\mathrm{RR}=1.40 ; 95 \% \mathrm{CI}$ : $1.14,1.73 ; P<0.05)$ 
Table 2: Progression free survival and serious adverse events for efficacy and safety in meta-analyses of direct comparisons between each pair of drugs

\begin{tabular}{|c|c|c|c|c|c|c|}
\hline & Number & Number & Efficacy & & Safety & \\
\hline & $\begin{array}{l}01 \\
\text { studies }\end{array}$ & patients & \begin{tabular}{|l} 
PFS \\
(median,mo.)
\end{tabular} & $\operatorname{SMD}(95 \% \mathrm{CI})$ & SAE(rate) & $\operatorname{RR}(95 \% \mathrm{CI})$ \\
\hline Sorafinib vs. Axitinib & 1 & 288 & $6.5 v s .10 .1$ & $\begin{array}{l}0.24 \\
(-0.01,0.48)\end{array}$ & 24/96vs.64/189 & $\begin{array}{l}0.74 \\
(0.50,1.10)\end{array}$ \\
\hline Tivozanib vs. Sorafinib & 1 & 517 & $11.9 v s .9 .1$ & \begin{tabular}{|l|}
-0.16 \\
$(-0.34,0.00)$ \\
\end{tabular} & 159/260vs.179/257 & \begin{tabular}{|l|l|}
0.88 \\
$(0.78,1.00)$
\end{tabular} \\
\hline $\begin{array}{l}\text { Bevacizumab+IFN- } \alpha \\
\text { IFN- } \alpha+\text { Placebo }\end{array}$ & 1 & 649 & $10.2 v s .5 .4$ & $\begin{array}{l}-6.85 \\
(-7.25,-6.45)\end{array}$ & $98 / 327 v s .50 / 304$ & $\begin{array}{l}1.82 \\
(1.35,2.44)\end{array}$ \\
\hline $\begin{array}{l}\text { Bevacizumab+ IFN- } \alpha \text { vs. } \\
\text { IFN- }\end{array}$ & 1 & 732 & $8.5 v s .5 .2$ & \begin{tabular}{|l|}
-0.29 \\
$(-0.43,-0.14)$ \\
\end{tabular} & $329 / 450 v s .231 / 388$ & $\begin{array}{l}1.27 \\
(1.15,1.39) \\
\end{array}$ \\
\hline $\begin{array}{lcc}\text { IFN- } \alpha \quad v s . & \text { IFN- } \alpha+\text { IL- } \\
2+\text { fluorouracil } & \\
\end{array}$ & 1 & 1006 & $5.5 v s .5 .3$ & \begin{tabular}{|l|}
-0.02 \\
$(-0.15,0.10)$ \\
\end{tabular} & $113 / 502 v s .131 / 504$ & $\begin{array}{l}0.87 \\
(0.69,1.08) \\
\end{array}$ \\
\hline Sunitinib $v s$. IFN- $\alpha$ & 1 & 750 & $11.0 v s .5 .0$ & $\begin{array}{l}-0.61 \\
(-0.75,-0.46) \\
\end{array}$ & 93/360vs. $170 / 375$ & $\begin{array}{l}0.57 \\
(0.46,0.70)\end{array}$ \\
\hline $\begin{array}{l}\text { IFN+bevacizumab } v s . \\
\text { Temsirolimus+bevacizumab }\end{array}$ & 1 & 791 & $9.3 v s .9 .1$ & $\begin{array}{l}-0.02 \\
(-0.16,0.12) \\
\end{array}$ & $177 / 393 v s .148 / 391$ & $\begin{array}{l}1.19 \\
(1.01,1.41)\end{array}$ \\
\hline Temsirolimus $v s$. IFN- $\alpha$ & 1 & 416 & $5.6 v s .3 .2$ & \begin{tabular}{|l|}
-0.26 \\
$(-0.46,-0.07)$
\end{tabular} & $82 / 208 v s .99 / 200$ & $\begin{array}{ll}0.42 \\
(0.27,0.67)\end{array}$ \\
\hline Pazopanib vs. Placebo & 1 & 435 & $9.2 v s .4 .2$ & \begin{tabular}{|l|}
-7.13 \\
$(-7.64,-6.62)$ \\
\end{tabular} & $76 / 290 v s .28 / 145$ & $\begin{array}{l}1.35 \\
(0.93,2.00) \\
\end{array}$ \\
\hline Pazopanib vs. Sunitinib & 1 & 1110 & $8.4 v s .9 .5$ & $\begin{array}{l}0.07 \\
(-0.05,0.19)\end{array}$ & $230 / 554 v s .224 / 548$ & $\begin{array}{l}0.98 \\
(0.86,1.13)\end{array}$ \\
\hline Sorafinib vs.Placebo & 1 & 903 & $5.5 v s .2 .8$ & \begin{tabular}{|l|}
-3.37 \\
$(-3.58,-3.17)$
\end{tabular} & $154 / 451 v s .110 / 452$ & $\begin{array}{l}1.40 \\
(1.14,1.73)\end{array}$ \\
\hline
\end{tabular}

Abbreviations: $\mathrm{SMD}=$ Standardized mean difference, $\mathrm{RR}=$ Risk ratio, $\mathrm{PFS}=$ Progression free survival, $\mathrm{SAE}=$ Serious adverse events, IL-2=Interleukin-2, IFN=Interferon

\section{Results from network meta-analysis of efficacy and safety}

From the eligible studies, 45 indirect comparisons were made. Results of all possible comparisons were expressed with risk ratios, standardized mean difference and $95 \%$ credible intervals calculated by Bayesian network meta-analysis. Figure 3 summarizes the results of the network meta-analysis. Only three statistically differences were found in efficacy comparisons. These results demonstrated that sunitinib had a significantly longer PFS than IFN- $\alpha$ (SMD $=-5.68$; 95\%CI: -10.76 ,$0.86 ; P<0.001)$ and placebo $(\mathrm{SMD}=-6.71 ; 95 \% \mathrm{CI}$ : $-12.65,-0.79 ; P<0.001)$; meanwhile, pazopanib had a significantly longer PFS in comparison to placebo (SMD $=5.13 ; 95 \% \mathrm{CI}: 0.43,10.09 ; P<0.001)$. Analysis of inconsistency between direct and indirect comparisons indicated that no statistically significant inconsistency was identified in PFS and SAE comparisons $(P>0.05)$.

Values of ranking probability column (Figure 4) indicated that sunitinib had the highest probability of being the best treatment modality in terms of PFS (value $=2.36$ ), followed by axitinib (value $=3.22$ ) and pazopanib (value $=3.69$ ). It was obvious that placebo had the lowest probability of being the best treatment modality (value
$=8.83)$, and IFN- $\alpha$ alone (value $=7.95)$ and interleukin alone (value $=7.93$ ) also had a rather low probability which were among the last three of the ranking. When it came to SAE (Figure 5), except for placebo (value $=8.06$ ), sunitinib (value $=7.43$ ) and pazopanib (value $=6.80$ ) had the highest probability of being the safest drugs as the first-line treatment. In contrast, bevacizumab combined with IFN- $\alpha$ (value $=2.52$ ) had the lowest probability, followed by axitinib (value $=3.42$ ). This analysis indicated that sunitinib seemed to be the best choice of first-line treatment for patients with $\mathrm{mRCC}$ because it had the most favorable balance between efficacy and safety.

\section{DISCUSSION}

In the present study, the results from our indirect comparisons indicated that sunitinib was more efficacious than IFN- $\alpha$ and placebo, which had significant differences between each pair of arms. The overall trend of our network meta-analysis was that targeted therapies had better efficacy and safety which was in accordance with previous studies [20]. Ranking of treatment arms showed that sunitinib had the highest probability of being the best first-line choice for patients with $\mathrm{mRCC}$, because sunitinib not only ranked top in terms of efficacy, but also ranked 
among the best of safety aspects.

Results from several phase 3 RCTs showed that patients treated with sunitinib as first-line treatment could survive for more than two years $[9,16]$. Those patients who had favorable risk factors could survive even much longer [21, 22]. Motzer RJ et al. conducted a randomized phase 3 trial to compare sunitinib and IFN- $\alpha$ in the first-line treatment of patients with $\mathrm{mRCC}$ and found that sunitinib demonstrated longer overall survival and progression-free survival [9]. The RECORD-3 trial concluded that everolimus did not yield better results compared with sunitinib as first-line therapy in patients with mRCC and suggested sunitinib be the standard treatment paradigm of first-line therapy [23]. Even though the efficacy of sunitinib has been validated by numerous RCTs, chronic sunitinib treatment still raises questions about its long-term safety. An expanded access trial in mRCC found that there were neither cumulative serious toxicities nor unexpected long-term treatment-related adverse events in patients with wide-ranging disease

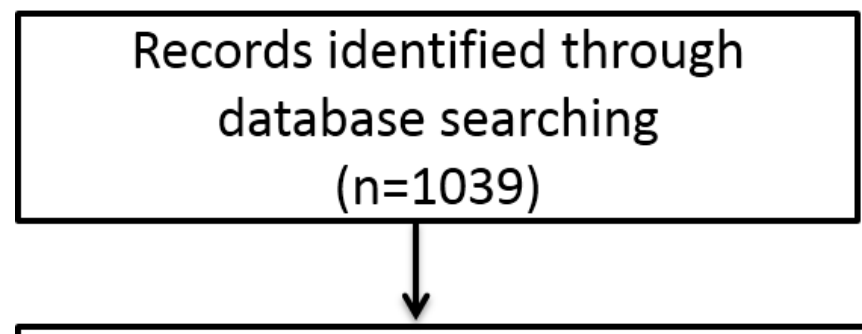

\section{Additional records identified through other sources}

$(n=214)$

\section{Records after duplicates removed}

( $n=1198)$

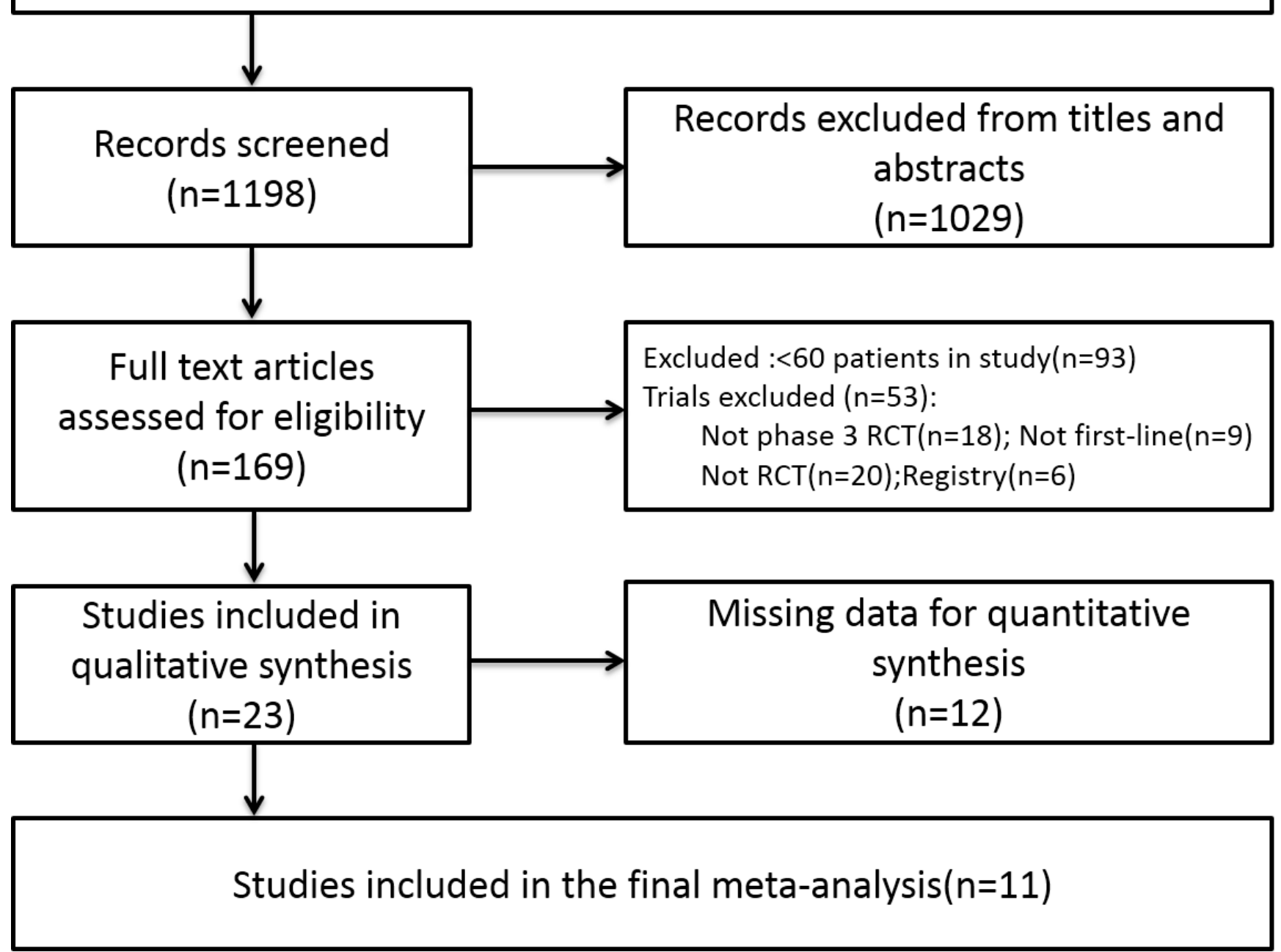

Figure 1: Flow chart of study selection 
states to receive sunitinib treatment [24]. Another group of investigators reported a further study of long-term safety for sunitinib using pooled data from 5739 patients with $\mathrm{mRCC}$ enrolled in nine prospective clinical trials, including 807 patients treated for $\geq 2$ yr. They found that chronic sunitinib treatment was not associated with new types or increased severity of treatment-related adverse events and toxicity was not cumulative except for hypothyroidism [25].

Targeted therapies are the main treatment modality

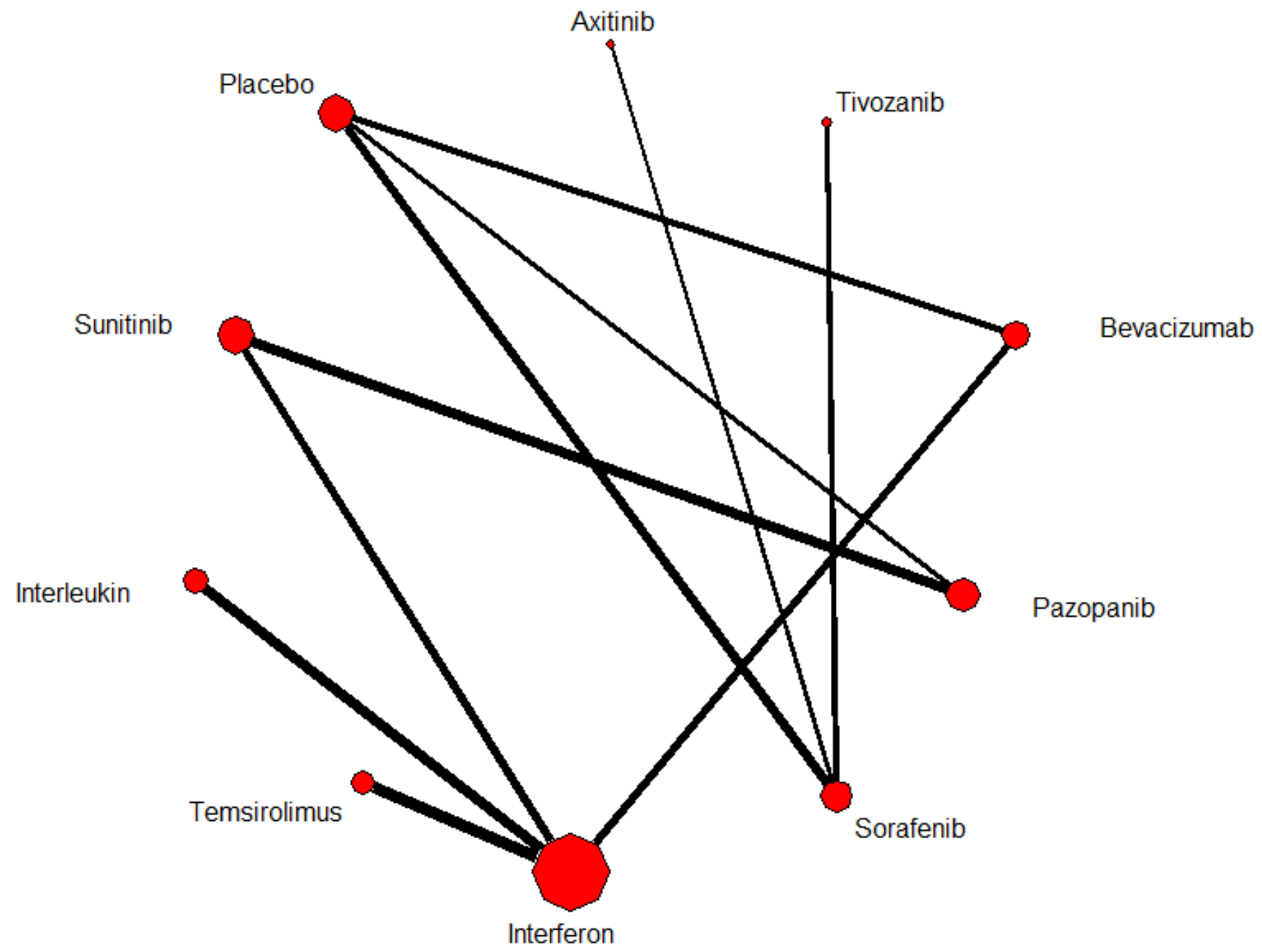

Figure 2: Network of eligible comparisons for the multiple-treatment meta-analysis for efficacy (progression free survival). Each link represents at least 1 study and the widths of each link are proportional to the number of studies comparing the particular arms. The size of each node is proportional to the total sample size.

\begin{tabular}{|c|c|c|c|c|c|c|c|c|c|}
\hline Axitinib & $\begin{array}{c}0.45 \\
(0.07, \quad 2,69) \\
\end{array}$ & $\begin{array}{c}1.13 \\
(0.14,9.41) \\
\end{array}$ & $\begin{array}{c}0.62 \\
(0.07,6.00) \\
\end{array}$ & $\begin{array}{c}0.75 \\
(0.06,9.90) \\
\end{array}$ & $\begin{array}{c}0.44 \\
(0.05,3.59) \\
\end{array}$ & $\begin{array}{c}0.40 \\
(0.07,2.38) \\
\end{array}$ & $\begin{array}{c}0.65 \\
(0.17,2.33) \\
\end{array}$ & $\begin{array}{c}0.34 \\
(0.04, \quad 3.27) \\
\end{array}$ & $\begin{array}{c}0.41 \\
(0.03,5.71) \\
\end{array}$ \\
\hline $\begin{array}{c}0.67 \\
(-7.95,9.33) \\
\end{array}$ & Tivozanib & $\begin{array}{c}2.58 \\
(0.33, \quad 19.67)\end{array}$ & $\begin{array}{c}1.41 \\
(0.16, \quad 12.84)\end{array}$ & $\begin{array}{c}1.68 \\
(0.15,21.50)\end{array}$ & $\begin{array}{c}0.99 \\
(0.13,7.94)\end{array}$ & $\begin{array}{c}0.90 \\
(0.16,5.07)\end{array}$ & $\begin{array}{c}1.46 \\
(0.43,5.12)\end{array}$ & $\begin{array}{c}0.77 \\
(0.09,7.20)\end{array}$ & $\begin{array}{c}0.94 \\
(0.08,12.39)\end{array}$ \\
\hline $\begin{array}{c}1.56 \\
(-7.63, \quad 11.67) \\
\end{array}$ & $\begin{array}{c}0.92 \\
(-8.40, \quad 10.30) \\
\end{array}$ & Bevacizumab & $\begin{array}{c}0.55 \\
(0.18,1.67)\end{array}$ & $\begin{array}{c}0.66 \\
(0.13,3.42)\end{array}$ & $\begin{array}{c}0.39 \\
(0.10,1.54)\end{array}$ & $\begin{array}{c}0.35 \\
(0.11,1.09)\end{array}$ & $\begin{array}{c}0.57 \\
(0.11, \quad 2.89)\end{array}$ & $\begin{array}{c}0.30 \\
(0.08,1.17)\end{array}$ & $\begin{array}{c}0.36 \\
(0.07,1.92)\end{array}$ \\
\hline $\begin{array}{c}5.21 \\
(-4.78, \quad 15.53)\end{array}$ & $\begin{array}{c}4.50 \\
(-5.67,14.70) \\
\end{array}$ & $\begin{array}{c}3.61 \\
(-1.48,8.38) \\
\end{array}$ & Interferon-alfa & $\begin{array}{c}1.20 \\
(0.36,4.16)\end{array}$ & $\begin{array}{c}0.71 \\
(0.19,2.74)\end{array}$ & $\begin{array}{c}0.65 \\
(0.16,2.47)\end{array}$ & $\begin{array}{c}1.04 \\
(0.16,6.23)\end{array}$ & $\begin{array}{c}0.55 \\
(0.18,1.67)\end{array}$ & $\begin{array}{c}0.67 \\
(0.19,2.29)\end{array}$ \\
\hline $\begin{array}{c}4.83 \\
(-7.37, \quad 15.29)\end{array}$ & $\begin{array}{c}3.98 \\
(-7.76, \quad 14.12)\end{array}$ & $\begin{array}{c}3.19 \\
(-4.73,8.94) \\
\end{array}$ & $\begin{array}{c}-0.44 \\
(-5.72,3.11) \\
\end{array}$ & Interleukin & $\begin{array}{c}0.58 \\
(0.10,3.52)\end{array}$ & $\begin{array}{c}0.53 \\
(0.08,3.21)\end{array}$ & $\begin{array}{c}0.86 \\
(0.10,7.50) \\
\end{array}$ & $\begin{array}{c}0.46 \\
(0.09,2.31) \\
\end{array}$ & $\begin{array}{c}0.55 \\
(0.10,3.15) \\
\end{array}$ \\
\hline $\begin{array}{c}1.08 \\
(-8.52,10.57) \\
\end{array}$ & $\begin{array}{c}0.38 \\
(-9.44,9.78)\end{array}$ & $\begin{array}{c}-0.47 \\
(-6.93,5.25)\end{array}$ & $\begin{array}{c}-4.14 \\
(-10.45,1.59)\end{array}$ & $\begin{array}{c}-3.74 \\
(-10.78,4.46)\end{array}$ & Pazopanib & $\begin{array}{c}0.91 \\
(0.29,2.81)\end{array}$ & $\begin{array}{c}1.47 \\
(0.27,7.80)\end{array}$ & $\begin{array}{c}0.78 \\
(0.25,2.28)\end{array}$ & $\begin{array}{c}0.95 \\
(0.15,5.98)\end{array}$ \\
\hline $\begin{array}{c}6.21 \\
(-2.01, \quad 14.40) \\
\end{array}$ & $\begin{array}{c}5.52 \\
(-2.66, \quad 13.58) \\
\end{array}$ & $\begin{array}{c}4.69 \\
(-0.62,9.33) \\
\end{array}$ & $\begin{array}{c}1.04 \\
(-5.15,6.94) \\
\end{array}$ & $\begin{array}{c}1.42 \\
(-5.35,9.71)\end{array}$ & $\frac{5,13}{(0,43,10,09)}$ & Placebo & $\begin{array}{c}1.61 \\
(0.48,5.31) \\
\end{array}$ & $\begin{array}{c}0.85 \\
(0.21,3.39)\end{array}$ & $\begin{array}{c}1.03 \\
(0.17,6.70)\end{array}$ \\
\hline $\begin{array}{c}3.58 \\
(-2.61,9.51)\end{array}$ & $\begin{array}{c}2.84 \\
(-3.49,8.64)\end{array}$ & $\begin{array}{c}2.01 \\
(-5.71,9.02)\end{array}$ & $\begin{array}{c}-1.65 \\
(-10.10,6.40)\end{array}$ & $\begin{array}{c}-1.31 \\
(-10.08,8.88)\end{array}$ & $\begin{array}{c}2.41 \\
(-4.77,9.98)\end{array}$ & $\begin{array}{c}-2.69 \\
(-8.29,2.72)\end{array}$ & Sorafenib & $\begin{array}{c}0.53 \\
(0.08,3.37)\end{array}$ & $\begin{array}{c}0.64 \\
(0.07,6.03)\end{array}$ \\
\hline $\begin{array}{c}-0.46 \\
(-10.56,9.78)\end{array}$ & $\begin{array}{c}-1.15 \\
(-11.33,8.74)\end{array}$ & $\begin{array}{c}-2.09 \\
(-8.51,3.84) \\
\end{array}$ & $\begin{array}{c}\frac{-5,68}{76,-0,86)} \\
\end{array}$ & $\begin{array}{c}-5.22 \\
(-11.23,2.04)\end{array}$ & $\begin{array}{c}-1.54 \\
(-6.23,3.50) \\
\end{array}$ & $\begin{array}{c}\frac{-6.71}{(-12,65,-0.69)} \\
\end{array}$ & $\begin{array}{c}-4.04 \\
(-12.06,4.02) \\
\end{array}$ & Sunitinib & $\begin{array}{c}1.22 \\
(0.22,6.35) \\
\end{array}$ \\
\hline $\begin{array}{c}4.19 \\
(-6.50,15.11)\end{array}$ & $\begin{array}{c}3.45 \\
(-7.06,14.37)\end{array}$ & $\begin{array}{c}2.59 \\
(-3.93,8.75)\end{array}$ & $\begin{array}{c}-1.06 \\
(-4.96,2.89)\end{array}$ & $\begin{array}{c}-0.59 \\
(-5.56,6.29)\end{array}$ & $\begin{array}{c}3.15 \\
(-3.84,10.60)\end{array}$ & $\begin{array}{c}-2.04 \\
(-9.16,5.21)\end{array}$ & $\begin{array}{c}0.67 \\
(-8.23,9.68)\end{array}$ & $\begin{array}{c}4.60 \\
(-1.52,11.10)\end{array}$ & Temsirolimus \\
\hline
\end{tabular}

Figure 3: Efficacy and safety of drugs in metastatic renal cell carcinoma 
for mRCC nowadays and targeted drugs are emerging in large numbers, however, it is difficult to establish standard which drug is better than the others in efficacy and safety because head-to-head studies about the medications themselves with each other are limited. The AXIS study was the first RCT to compare two targeted therapies of advanced RCC [26]. The results of this randomized phase 3 trial showed that axitinib resulted in significantly longer PFS compared with sorafenib (6.7vs.4.7months, $\mathrm{HR}=0.665,95 \% \mathrm{CI}: 0.544-0.812)$. When it came to safety, toxic effects in 14 (4\%) of 359 patients treated with axitinib resulted in treatment discontinuation and $29(8 \%)$ of 355 patients treated with sorafenib. A recent meta-analysis also concluded that axitinib was superior to sorafenib $(\mathrm{HR}=0.46,95 \% \mathrm{CI}: 0.32-0.68)$ in prolonging PFS [27]. However, the results from our network meta-analysis indicated that axitinib didn't exhibited a significantly higher efficacy than sorafenib $(\mathrm{SMD}=3.58$, $95 \% \mathrm{CI}:-2.61,9.51)$ as first-line therapy. A safe conclusion can be drawn that axitinib may be a treatment option for second-line therapy of mRCC. Several other head-tohead studies involving two different targeted drugs or one targeted drug versus the other cytokine drug as first-line therapies demonstrated significant results. The phase 3 AVOREN and CALGB 90206 trials reported significant PFS benefit of bevacizumab plus IFN- $\alpha$, which confirmed that the combination of IFN- $\alpha$ and bevacizumab remained as a first-line option of care for patients with $\operatorname{mRCC}[12$, 13]. However, there were significantly more SAEs for bevacizumab plus IFN- $\alpha$ than monotherapy. In our present network meta-analysis, we found that bevacizumab combined with IFN- $\alpha$ had the lowest probability of being the safest therapy for patients with $\mathrm{mRCC}$ as first-line option. Consensus has been reached that targeted therapies are more efficacious and safer than cytokine therapies which is in accordance with results from our network meta-analysis [9, 19].

Although sunitinib and other targeted therapies

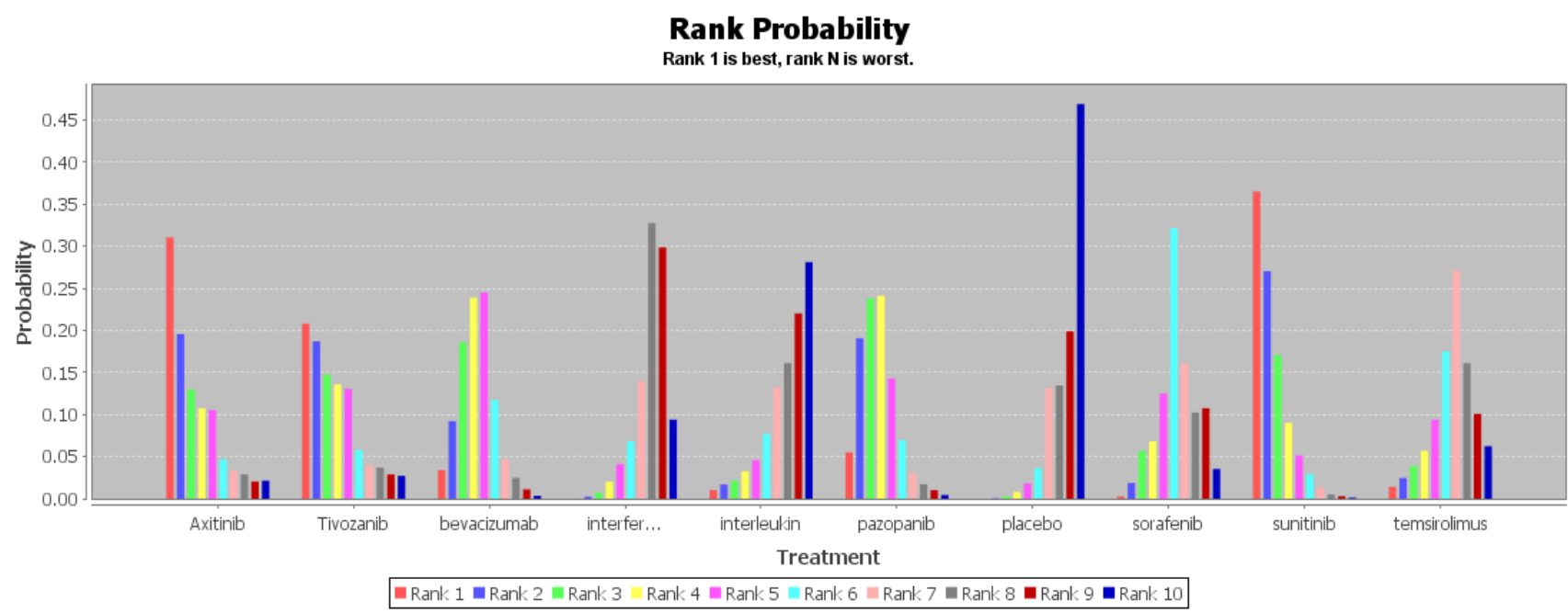

Figure 4: Rank probability of progression free survival

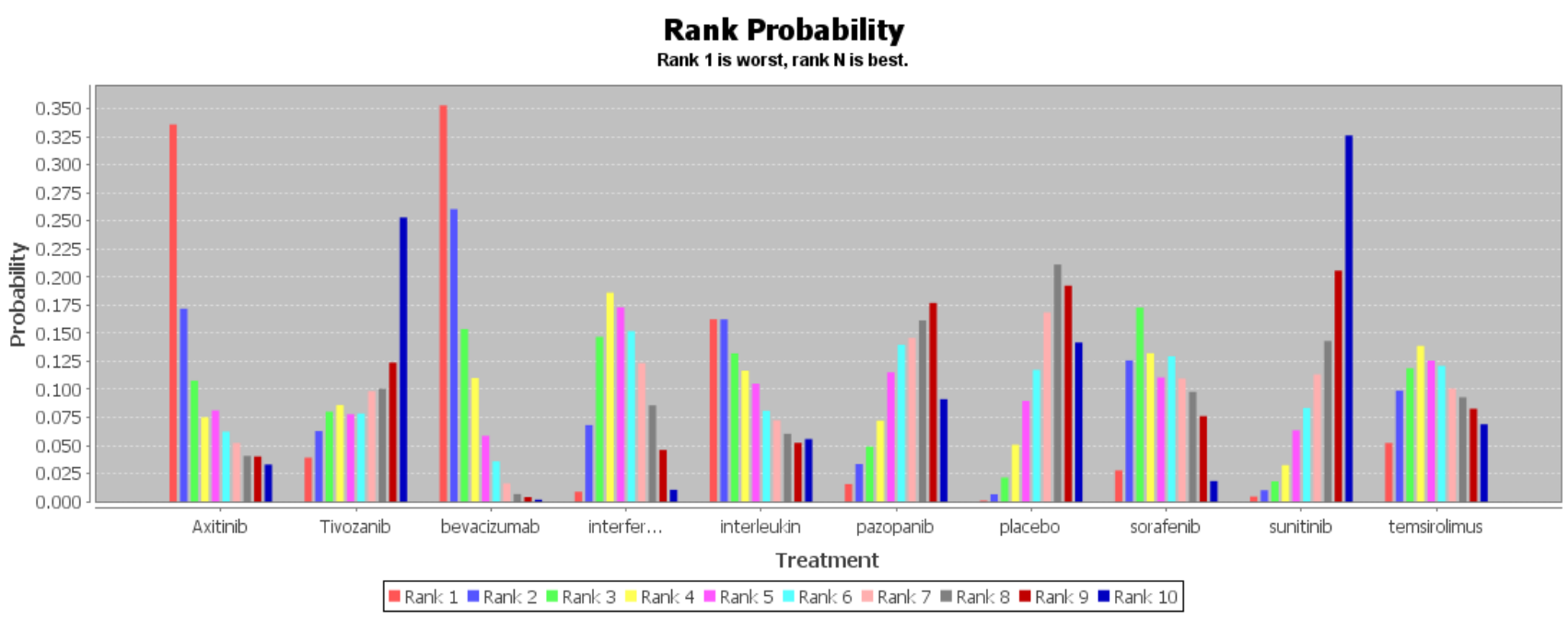

Figure 5: Rank probability of serious adverse events 
have changed the therapeutic landscape for mRCC, these treatment modalities will achieve limited overall survival after a given agent is no longer effective [28]. Thus, there is an urgent need for treatment options with novel mechanisms of action that could potentially result in improved efficacy and survival advantage. Recent understanding of host-tumor immune interactions has given rise to novel antibodies directed against immune checkpoint proteins which play a vital role in molecular immune response [29]. A randomized, open-label, phase 3 study compared nivolumab (a programmed death 1 checkpoint inhibitor) with everolimus in patients with $\mathrm{mRCC}$ who had received previous treatment concluded that overall survival was longer and fewer grade 3 or 4 adverse events occurred with nivolumab [28]. Immune checkpoint inhibitor antibodies are hopeful to be an important therapy for $\mathrm{mRCC}$, even to be first-line option.

There are several limitations should be acknowledged in this study. First of all, our studies included only phase 3 RCTs which resulted in selective bias. Because the quality of the included studies will influence the results of meta-analyses, our analysis was limited to prospective RCTs with sufficient sample size. Second, we did not conduct subgroup analysis according to patient characteristics and prior treatments. As we hoped to measure the overall treatment effect of medications for $\mathrm{mRCC}$, so we included patients meeting the eligibility criteria regardless of their characteristics. Lastly, the failure to acquire several unpublished data led to potential publication bias, even though great efforts had been made to seek for all the available data. Meta-analyses are subject to publication bias because studies with negative results are less likely to be published, therefore resulting in an overestimation.

In conclusion, the results of this network metaanalysis indicated that most of targeted therapies were more efficacious and safer than the other drugs for $\mathrm{mRCC}$. To be specific, sunitinib might be the best choice for clinicians and patients to be considered when both efficacy and safety were balanced. Further information to determine the optimal treatment strategy for $\mathrm{mRCC}$ is likely to be from future randomized trials that should examine combined therapies of these active agents. Meanwhile it is important that further comprehensive head-to-head RCTs are carried out for the purpose of assessing the relative efficacy and safety of treatments for $\mathrm{mRCC}$.

\section{MATERIALS AND METHODS}

\section{Search strategy}

We did a systemic search for randomized clinical trials of treatments for $\mathrm{mRCC}$ without language restriction until January 31, 2016. All studies were selected according to the search strategy based on Preferred Reporting Items for Systematic Reviews and Meta-analyses criteria (PRISMA)[30]. Two individuals (XC and FZ) searched the following databases and sources independently: PubMed, Embase, the Cochrane Central Register of Controlled Trials (in the Cochrane Library), and unpublished studies were also sought through "clinicaltrials.gov". The searches combined terms "metastatic renal cell carcinoma", "advanced renal cell carcinoma", "randomized controlled trials", or "RCTs" with the cancer MeSH heading "neoplasms". We attempted contact with the study authors through email and telephone to obtain full information when necessary.

\section{Eligibility criteria}

We included all the phase 3 RCTs evaluating the therapeutic efficacy and safety of any drug for the firstline treatment of mRCC. We included trials at least with a control intervention, enrolling at least 60 patients with any age, sex or race, and reporting the outcomes of interest (PFS, overall survival (OS), objective response rate (ORR), SAEs, etc.). Non-randomized trials, early results presentations, non-primary studies, animal/laboratory studies, and researches published only in protocols or in abstracts were excluded from present analysis.

\section{Study selection and data extraction}

Two investigators (XC and FZ) independently evaluated the risk of bias and extracted data from eligible trials. If only the standard deviations were missing, they were estimated from $p$ values or with the mean standard deviation of the other included studies [31]. Extracted data were entered into standardized Excel (Microsoft Corp) file and were checked by another author (TL). Any disagreements were resolved by discussion and consensus. To assess the risk of bias of individual trials, we applied the following components recommended by the Cochrane Collaboration: random sequence generation; allocation concealment; blinding of participants, personnel, and outcome assessors (with blinding of at least the outcome assessors required for considering this parameter as low risk of bias); incomplete outcome data; selective outcome reporting; and other sources of bias [32].

\section{Efficacy and safety outcomes}

Efficacy outcomes were primary endpoint including PFS as defined by investigators and secondary endpoints including OS, duration of treatment response, and ORR. Safety outcomes included treatment-related SAEs, which were defined as grade 3 or 4 adverse events, and details on 
deaths when available.

\section{Statistical analysis}

To incorporate direct comparisons within two trials between two treatments and indirect comparisons from trials having one treatment in common, network metaanalysis methods were applied to all available treatment comparisons to provide the most comprehensive evidence. We compared outcome analyses using risk ratios (RR), standardized mean difference (SMD) and 95\% credible intervals $(95 \% \mathrm{CI})$ with a Bayesian hierarchical random effects model. We used the random effects rather than the fixed effects model because this was likely the most appropriate and conservative analysis to account for differences among trials. We also conducted additional sensitivity analyses by repeating the main computations with the fixed effects method to evaluate the consistency of the results. Potential inconsistency of the network was evaluated by the node split method, measuring agreement between direct and indirect evidence for each split node. Data were analyzed according to the intention to treat principle. Ranking of treatment arms was calculating according to ranking probability column provided by the Bayesian network meta-analysis to determine the best rank. A $p$ value $<0.05$ was judged as statistically significant, except where otherwise specified. All analyses were conducted with ADDIS version1.16.5 (Copyright (C)2013, Gert van Valkenhoef, Joël Kuiper) and R version 2.10.1 (Copyright (C) 2009, The R Foundation for Statistical Computing, ISBN 3-900051-07-0).

\section{CONFLICTS OF INTEREST}

We have no financial disclosures to declare and no conflicts of interest.

\section{GRANT SUPPORT}

This work was supported by Fundamental Research Funds for the Central Universities and Jiangsu Graduate Student Innovation Grant (No. KYZZ15_0066) and Excellent Doctoral Dissertations Cultivation Fund from Southeast University.

\section{Authors' contributions}

$\mathrm{XC}$ has full access to all the data in the study and takes responsibility for the integrity of the data and the accuracy of the data analysis.

Study concept and design: HG, TL.

Acquisition of data: XC, FZ.

Analysis and interpretation of data: TL, FZ.

Drafting of the manuscript: XC.

Critical revision of the manuscript for important intellectual content: XZ, LX, GL. Statistical analysis: TL, RY.

Administrative, technical, or material support: $\mathrm{HG}$,

CJ.

Supervision: HG.

\section{REFERENCES}

1. Ferlay J, Autier P, Boniol M, Heanue M, Colombet M, Boyle P. Estimates of the cancer incidence and mortality in Europe in 2006. Ann Oncol. 2007. 18: 581-92.

2. Escudier B, Pluzanska A, Koralewski P, Ravaud A, Bracarda S, Szczylik C, Chevreau C, Filipek M, Melichar B, Bajetta E, Gorbunova V, Bay JO, Bodrogi I, et al. Bevacizumab plus interferon alfa-2a for treatment of metastatic renal cell carcinoma: a randomised, double-blind phase III trial. Lancet. 2007. 370: 2103-11.

3. Wood C, Srivastava P, Bukowski R, Lacombe L, Gorelov AI, Gorelov S, Mulders P, Zielinski H, Hoos A, Teofilovici F, Isakov L, Flanigan R, Figlin R, et al. An adjuvant autologous therapeutic vaccine (HSPPC-96; vitespen) versus observation alone for patients at high risk of recurrence after nephrectomy for renal cell carcinoma: a multicentre, open-label, randomised phase III trial. Lancet. 2008. 372: 145-54.

4. Coppin C, Porzsolt F, Awa A, Kumpf J, Coldman A, Wilt T. Immunotherapy for advanced renal cell cancer. Cochrane Database Syst Rev. 2005. : CD001425.

5. Motzer RJ, Basch E. Targeted drugs for metastatic renal cell carcinoma. Lancet. 2007. 370: 2071-3.

6. Escudier B, Porta C, Schmidinger M, Algaba F, Patard JJ, Khoo V, Eisen T, Horwich A. Renal cell carcinoma: ESMO Clinical Practice Guidelines for diagnosis, treatment and follow-up. Ann Oncol. 2014. 25 Suppl 3: iii49-56.

7. Escudier B, Eisen T, Stadler WM, Szczylik C, Oudard S, Siebels M, Negrier S, Chevreau C, Solska E, Desai AA, Rolland F, Demkow T, Hutson TE, et al. Sorafenib in advanced clear-cell renal-cell carcinoma. N Engl J Med. 2007. 356: 125-34.

8. Motzer RJ, Hutson TE, Tomczak P, Michaelson MD, Bukowski RM, Rixe O, Oudard S, Negrier S, Szczylik C, Kim ST, Chen I, Bycott PW, Baum CM, et al. Sunitinib versus interferon alfa in metastatic renal-cell carcinoma. $\mathrm{N}$ Engl J Med. 2007. 356: 115-24.

9. Motzer RJ, Hutson TE, Tomczak P, Michaelson MD, Bukowski RM, Oudard S, Negrier S, Szczylik C, Pili R, Bjarnason GA, Garcia-del-Muro X, Sosman JA, Solska E, et al. Overall survival and updated results for sunitinib compared with interferon alfa in patients with metastatic renal cell carcinoma. J Clin Oncol. 2009. 27: 3584-90.

10. Sternberg CN, Davis ID, Mardiak J, Szczylik C, Lee E, Wagstaff J, Barrios CH, Salman P, Gladkov OA, Kavina A, Zarba JJ, Chen M, McCann L, et al. Pazopanib in locally advanced or metastatic renal cell carcinoma: results of a 
randomized phase III trial. J Clin Oncol. 2010. 28: 1061-8.

11. Gore ME, Griffin CL, Hancock B, Patel PM, Pyle L, Aitchison M, James N, Oliver RT, Mardiak J, Hussain T, Sylvester R, Parmar MK, Royston P, et al. Interferon alfa2a versus combination therapy with interferon alfa- $2 \mathrm{a}$, interleukin-2, and fluorouracil in patients with untreated metastatic renal cell carcinoma (MRC RE04/EORTC GU 30012): an open-label randomised trial. Lancet. 2010. 375: 641-8.

12. Escudier B, Bellmunt J, Negrier S, Bajetta E, Melichar B, Bracarda S, Ravaud A, Golding S, Jethwa S, Sneller V. Phase III trial of bevacizumab plus interferon alfa-2a in patients with metastatic renal cell carcinoma (AVOREN): final analysis of overall survival. J Clin Oncol. 2010. 28: 2144-50.

13. Rini BI, Halabi S, Rosenberg JE, Stadler WM, Vaena DA, Archer L, Atkins JN, Picus J, Czaykowski P, Dutcher J, Small EJ. Phase III trial of bevacizumab plus interferon alfa versus interferon alfa monotherapy in patients with metastatic renal cell carcinoma: final results of CALGB 90206. J Clin Oncol. 2010. 28: 2137-43.

14. Rini BI, Bellmunt J, Clancy J, Wang K, Niethammer AG, Hariharan S, Escudier B. Randomized phase III trial of temsirolimus and bevacizumab versus interferon alfa and bevacizumab in metastatic renal cell carcinoma: INTORACT trial. J Clin Oncol. 2014. 32: 752-9.

15. Escudier B, Eisen T, Stadler WM, Szczylik C, Oudard S, Staehler M, Negrier S, Chevreau C, Desai AA, Rolland F, Demkow T, Hutson TE, Gore M, et al. Sorafenib for treatment of renal cell carcinoma: Final efficacy and safety results of the phase III treatment approaches in renal cancer global evaluation trial. J Clin Oncol. 2009. 27: 3312-8.

16. Motzer RJ, Hutson TE, Cella D, Reeves J, Hawkins R, Guo J, Nathan P, Staehler M, de Souza P, Merchan JR, Boleti E, Fife K, Jin J, et al. Pazopanib versus sunitinib in metastatic renal-cell carcinoma. N Engl J Med. 2013. 369: 722-31.

17. Motzer RJ, Nosov D, Eisen T, Bondarenko I, Lesovoy V, Lipatov O, Tomczak P, Lyulko O, Alyasova A, Harza M, Kogan M, Alekseev BY, Sternberg CN, et al. Tivozanib versus sorafenib as initial targeted therapy for patients with metastatic renal cell carcinoma: results from a phase III trial. J Clin Oncol. 2013. 31: 3791-9.

18. Hutson TE, Lesovoy V, Al-Shukri S, Stus VP, Lipatov ON, Bair AH, Rosbrook B, Chen C, Kim S, Vogelzang NJ. Axitinib versus sorafenib as first-line therapy in patients with metastatic renal-cell carcinoma: a randomised openlabel phase 3 trial. Lancet Oncol. 2013. 14: 1287-94.

19. Hudes G, Carducci M, Tomczak P, Dutcher J, Figlin R, Kapoor A, Staroslawska E, Sosman J, McDermott D, Bodrogi I, Kovacevic Z, Lesovoy V, Schmidt-Wolf IG, et al. Temsirolimus, interferon alfa, or both for advanced renal-cell carcinoma. N Engl J Med. 2007. 356: 2271-81.

20. Mills EJ, Rachlis B, O'Regan C, Thabane L, Perri D. Metastatic renal cell cancer treatments: an indirect comparison meta-analysis. BMC Cancer. 2009. 9: 34.
21. Motzer RJ, Escudier B, Bukowski R, Rini BI, Hutson TE, Barrios CH, Lin X, Fly K, Matczak E, Gore ME. Prognostic factors for survival in 1059 patients treated with sunitinib for metastatic renal cell carcinoma. Br J Cancer. 2013. 108: 2470-7.

22. Motzer RJ, Hutson TE, McCann L, Deen K, Choueiri TK. Overall survival in renal-cell carcinoma with pazopanib versus sunitinib. N Engl J Med. 2014. 370: 1769-70.

23. Motzer RJ, Barrios CH, Kim TM, Falcon S, Cosgriff T, Harker WG, Srimuninnimit V, Pittman K, Sabbatini R, Rha SY, Flaig TW, Page R, Bavbek S, et al. Phase II randomized trial comparing sequential first-line everolimus and secondline sunitinib versus first-line sunitinib and second-line everolimus in patients with metastatic renal cell carcinoma. J Clin Oncol. 2014. 32: 2765-72.

24. Gore ME, Szczylik C, Porta C, Bracarda S, Bjarnason GA, Oudard S, Lee SH, Haanen J, Castellano D, Vrdoljak E, Schoffski P, Mainwaring P, Hawkins RE, et al. Final results from the large sunitinib global expanded-access trial in metastatic renal cell carcinoma. Br J Cancer. 2015. 113: 12-9.

25. Porta C, Gore ME, Rini BI, Escudier B, Hariharan S, Charles LP, Yang L, DeAnnuntis L, Motzer RJ. Long-term Safety of Sunitinib in Metastatic Renal Cell Carcinoma. Eur Urol. 2016. 69: 345-51.

26. Rini BI, Escudier B, Tomczak P, Kaprin A, Szczylik C, Hutson TE, Michaelson MD, Gorbunova VA, Gore ME, Rusakov IG, Negrier S, Ou YC, Castellano D, et al. Comparative effectiveness of axitinib versus sorafenib in advanced renal cell carcinoma (AXIS): a randomised phase 3 trial. Lancet. 2011. 378: 1931-9.

27. Leung HW, Chan AL, Lin SJ. Indirect comparisons of efficacy and safety between seven newer targeted agents for metastatic renal cell carcinoma: A network meta-analysis of randomised clinical trials. Mol Clin Oncol. 2014. 2: 858864.

28. Motzer RJ, Escudier B, McDermott DF, George S, Hammers HJ, Srinivas S, Tykodi SS, Sosman JA, Procopio G, Plimack ER, Castellano D, Choueiri TK, Gurney H, et al. Nivolumab versus Everolimus in Advanced Renal-Cell Carcinoma. N Engl J Med. 2015. 373: 1803-13.

29. Inman BA, Harrison MR, George DJ. Novel immunotherapeutic strategies in development for renal cell carcinoma. Eur Urol. 2013. 63: 881-9.

30. Liberati A, Altman DG, Tetzlaff J, Mulrow C, Gotzsche PC, Ioannidis JP, Clarke M, Devereaux PJ, Kleijnen J, Moher D. The PRISMA statement for reporting systematic reviews and meta-analyses of studies that evaluate health care interventions: explanation and elaboration. Ann Intern Med. 2009. 151: W65-94.

31. Furukawa TA, Barbui C, Cipriani A, Brambilla P, Watanabe $\mathrm{N}$. Imputing missing standard deviations in meta-analyses can provide accurate results. J Clin Epidemiol. 2006. 59: 7-10. 
32. Schulz KF, Chalmers I, Hayes RJ, Altman DG. Empirical evidence of bias. Dimensions of methodological quality associated with estimates of treatment effects in controlled trials. JAMA. 1995. 273: 408-12. 